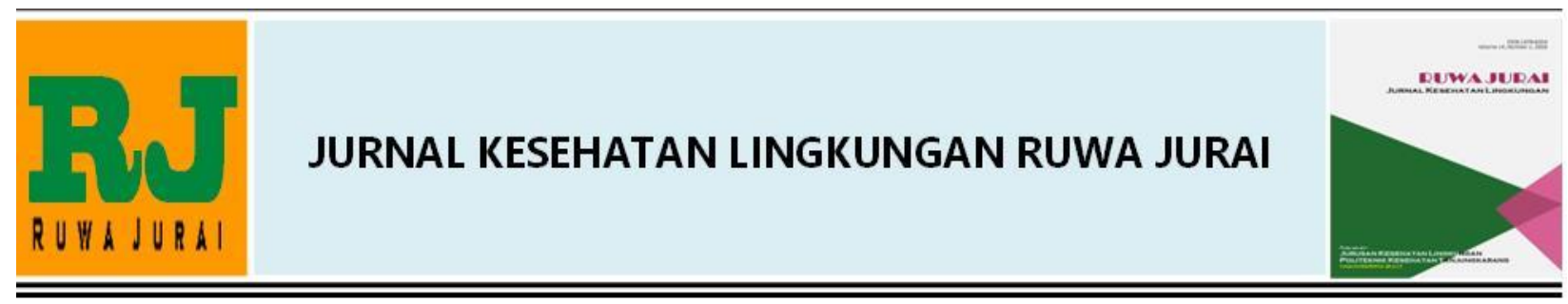

\title{
STUDI EKTOPARASIT PADA TIKUS DI PELABUHAN KUALA TUNGKAL TAHUN 2019
}

\author{
Nadya Husna ${ }^{1 *}$, Emilia Chandra ${ }^{2}$ \\ 1,2 Department of Environmental Health, Poltekkes Kemenkes Jambi
}

\section{Artikel Info : \\ Received 2 Agustus 2020 \\ Accepted 14 September 2020 \\ Available online 31 Desember 2020}

Editor: Amrul Hasan

Key word :

Rodent, ectoparasites,

Xenopshylla cheopis

Kata Kunci :

Tikus, ektoparasit

Xenopshylla cheopis

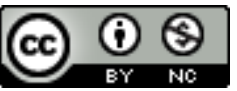

Ruwa Jurai: Jurnal

Kesehatan Lingkungan is licensed

under a Creative Commons

Attribution-NonCommercial 4.0

International License.

\begin{abstract}
Ectoparasites are parasites that live on rats as their hosts, and the port is one of the breeding grounds for rats that must be protected or a place that must be free from rats. Rats can contain ectoparasites that are harmful to human health. This study aims to see the description of ectoparasites in rats at Kuala Tungkal Port, Jambi Province. This study is an exploratory study, which describes ectoparasites in rats in the Kuala Tungkal Port Health Office with an area of $280,000 \mathrm{~m} 2$. The research was carried out by installing traps at points that represent the presence of rats. The results found 3 types of mice, namely Mus musculus, Rattus diardii, and Rattus norvegicus, the most types of mice found were Mus musculus. Xenopshylla cheopis ectoparasite was found in Rattus diardii rats. It is necessary to monitor and control rat eradication in the port working area, as well as improve sanitation.

Ektoparasit adalah parasit yang hidup pada tubuh tikus sebagai inangnya, dan pelabuhan adalah salah satu tempat perkembangbiakan tikus yang harus dijaga atau tempat yang harus terbebas dari tikus. Tikus bisa mengandung Ektoparasit yang berbahaya bagi kesehatan manusia. Penelitian ini bertujuan untuk melihat gambaran ektoparasit pada tikus di Pelabuhan Kuala Tungkal Provinsi Jambi. Penelitian ini merupakan penelitian ekploratif, yang mendeskripsikan ektoparasit pada tikus yang ada di wilayah Kantor Kesehatan Pelabuhan Kuala Tungkal dengan luas $280.000 \mathrm{~m}^{2}$. Penelitian dilakukan dengan pemasangan perangkap pada titik yang mewakili keberadaan tikus. Hasil penelitian ditemukan 3 jenis tikus yaitu Musmusculus, Rattus diardii dan Rattus norvegicus, jenis tikus terbanyak yang di temukan adalah Musmusculus. Ditemukan ektoparasit Xenopshylla cheopis pada tikus Rattus diardii. Perlu dilakukan pengawasan dan pengendalian tindak hapus tikus di wilayah kerja pelabuhan, serta perbaikan sanitasi.
\end{abstract}

* Corresponding author : Emilia Chandra

Jurusan Kesehatan Lingkungan Poltekkes Kemenkes Jambi, Indonesia

J. H. Agus Salim No.09, Paal Lima, Kec. Kota Baru, Kota Jambi, Jambi 36128

Email : emilea@yahoo.co.id

\section{PENDAHULUAN}

Pelabuhan adalah tempat yang terdiri atas daratan dan/atau perairan dengan batas-batas tertentu sebagai tempat kegiatan pemerintahan dan kegiatan pengusahaan yang di pergunakan sebagai tempat kapal bersandar, naik turun penumpang, dan/atau bongkar muat barang. Pelabuhan tentu memiliki kantor yang berfungsi untuk mengatur keluar masuknya barang maupun manusia yang biasa di sebut Kantor Kesehatan Pelabuhan yang selanjutnya di singkat KKP, merupakan unit pelaksana teknis kementerian kesehatan di wilayah pelabuhan atau bandar udara (Kementerian Kesehatan RI, 2014).

KKP Jambi merupakan unit pelaksana teknis yang berada di bawah dan bertanggung jawab kepada Direktur Jenderal Pencegahan Dan Pengendalian Penyakit Kementerian Kesehatan.

Salah satu tugas KKP adalah melakukan pengendalian dampak kesehatan lingkungan dengan melakukan pengendalian risiko lingkungan melalui memberantas serangga penularan penyakit, tikus dan pinjal di lingkungan pelabuhan (Kementerian Kesehatan 
$\mathrm{RI}, 2008)$. Pelabuhan Jambi memiliki lima wilayah kerja, salah satunya adalah wilayah kerja pelabuhan Kuala Tungkal yang berada di Kabupaten Tanjung Jabung Barat, terletak di Muara Sungai Pengabuan yang berjarak \pm 200 Km dari Kota Jambi.

Pelabuhan sebagai salah satu sarana untuk melabuhkan kapal laut serta aktivitas bongkar muat barang, serta keluar masuknya sekelompok manusia. Sehingga areal pelabuhan menjadi salah satu faktor penting suburnya pertumbuhan populasi vektor yang dapat beresiko yang menjadi sumber penularan penyakit. Pelabuhan perlu di awasi karena salah satu tugas dari KKP adalah pengendalian risiko lingkungan dan kesehatan lintas wilayah, salah satunya upaya mencegah penyebaran penyakit karantina dan penyakit penularan wabah melalui pemutusan mata rantai penularan penyakit. pengendalian risiko lingkungan bertujuan untuk membuat wilayah pelabuhan dan alat angkut tidak menjadi sumber penularan ataupun habitat yang subur bagi perkembangbiakan vektor penyakit.

Menurut Permenkes No. 50 Tahun 2017 menyatakan, vektor adalah antropoda yang dapat menularkan, memindahkan, dan/atau menjadi sumber penular penyakit. Salah satu vektor yang terdapat di areal pelabuhan adalah Xenopsylla cheopis yang hidup sebagai ektoparasit pada tubuh tikus. Ektoparasit adalah parasit yang hidup di bagian luar tubuh inangnya, sebagian kelompok ektoparasit adalah golongan serangga (Hadi \& Supriyono, 2017). Menurut Permenkes No. 34 Tahun 2013, tindakan hapus tikus adalah prosedur untuk memberantas atau membunuh tikus yang terdapat pada alat angkut di pelabuhan, bandar udara dan pos lintas batas darat (Kementerian Kesehatan RI, 2013).

Tikus termasuk ke dalam Kingdom Animalia, kelas Mamalia, merupakan satwa liar yang sangat sering berhubungan dengan manusia. Tikus bersifat merugikan manusia, terutama di bidang pertanian, konstruksi, dan kesehatan. Tikus berpotensi merugikan kesehatan masyarakat karena berperan sebagai perantara penyakit, antara lain penyakit Pes dan Leptospirosis. Penyakit Pes adalah penyakit yang disebabkan oleh bakteri Yersinia pestis dengan vektor penular adalah pinjal Xenopsylla cheopis yang hidup sebagai ektoparasit pada tikus. Sedangkan leptosirosis di sebabkan oleh kuman Leptospira yang terdapat di dalam air kencing tikus yang bisa beresiko masuk ke tubuh jika adanya luka di kulit, kebiasaan berjalan tanpa alas kaki, kontak dengan tikus maupun urin Tikus dan kontak dengan jaringan hewan lain yang terinfeksi Leptospira seperti pinjal (Rusmini, 2011).

Persebaran penyakit pes di Indonesia tak lepas dari peranan pelabuhan sebagai pintu masuk arus angkutan, penumpang dan barang sekaligus berpotensi sebagai pintu gerbang transformasi penyebaran penyakit yang berdampak pada kesehatan masyarakat. Penyakit pes telah menimbulkan banyak kematian pada manusia di daratan Eropa, Asia dan Afrika, terutama pada abad ke-14 sampai 20. Meskipun akhir-akhir ini wabah penyakit pes tidak terjadi, namun kehadirannya harus selalu diwaspadai. Oleh karena itu perlu dilakukan upaya pengendalian. Pengendalian adalah upaya untuk mengurangi atau melenyapkan faktor risiko penyakit dan/atau gangguan kesehatan (Kementerian Kesehatan RI, 2017).

KKP Jambi juga telah melakukan pencanangan Gerakan Masyarakat Peduli Pengendalian Vektor dan Binatang Pembawa Penyakit (Gemalian Vektor dan BPP). Data KKP Jambi pada tahun 2016 dan 2017, menunjukkan populasi tikus yang tinggi di area pelabuhan, terutama di Kuala Tungkal (Tabel 1).

Tabel 1. Hasil Survei Tikus di Wilayah Kerja KKP Jambi tahun 2016-2017

\begin{tabular}{|c|c|c|c|c|c|}
\hline \multirow[t]{2}{*}{ No } & \multirow[t]{2}{*}{ Wilayah Kerja } & \multicolumn{2}{|c|}{ Jumlah tikus tertangkap } & \multicolumn{2}{|c|}{ Ektoparasit yang di temukan } \\
\hline & & 2016 & 2017 & 2016 & 2017 \\
\hline 1 & Bandara & 20 & 33 & Tidak di temukan & Tidak di temukan \\
\hline 2 & Talang Duku & 48 & 23 & Tidak di temukan & Tidak di temukan \\
\hline 3 & Muara Sabak & 21 & 92 & Tidak di temukan & Tidak di temukan \\
\hline 4 & Kuala Tungkal & 279 & 116 & Tidak di temukan & Tidak di temukan \\
\hline 5 & Nipah Panjang & 80 & 17 & Tidak di temukan & Tidak di temukan \\
\hline
\end{tabular}

Sumber : Laporan KKP Jambi, 2018 (KLW, 2017; Pelabuhan, 2016) 
Tingginya populasi tikus di area pelabuhan (Tabel 1), memberikasn risiko terhadap kesehatan masyarakar di sekitar pelabuhan. Penelitian bertujuan melakukan studi ektoparasit pada tikus di KKP Jambi, Wilayah Kerja Pelabuhan Kuala Tungkal Provinsi Jambi.

\section{METODE}

Penelitian bersifat deskriptif eksploratif, dengan metode observasi, mendeskripsikan ektoparasit pada tikus di KKP Jambi, Wilayah Kerja Pelabuhan Kuala Tungkal, Kabupaten Tanjung Jabung Barat, Provinsi Jambi. Pelabuhan Kuala Tungkal terletak di Muara Sungai Pengabuan yang berjarak $\pm 200 \mathrm{Km}$ dari Kota Jambi.

Penelitian dilaksanakan dengan cara penangkapan tikus di gudang, bangunan rumah, kebun sekitar rumah, dan bangunan perkantoran. Penangkapan dilakukan selama 5 hari di areal pelabuhan Kuala Tungkal, pada tanggal 1 Februari sampai dengan 5 Februari tahun 2019. Penentuan lokasi pemasangan perangkap tikus dengan umpan kelapa bakar, berdasarkan tanda-tanda yang menunjukkan keberadaan tikus, antara lain terdapat bekas tubuh pada dinding, kencing tikus, dan kotoran tikus.
Tikus yang terperangkap dibius menggunakan Chloroform, selanjutnya dilakukan identifikasi untuk mengetahui karakteristik dan jenis tikus. Untuk mendapatkan pinjal atau kutu sebagai ektoparasit tikus, dilakukan penyeritan menggunakan sisir serit.

\section{HASIL}

Pemasangan perangkap dilakukan selama 5 hari. Pada hari pertama didapatkan 10 ekor tikus yaitu Mus musculus (5 ekor), Rattus norvegicus (2 ekor) dan Rattus rattus diardii (2 ekor). Pada hari kedua didapatkan 5 ekor tikus yaitu Mus musculus (3 ekor), Rattus rattus diardii (1 ekor) dan Rattus norvegicus (1 ekor). Hari ketiga di dapatkan 2 ekor tikus Musmusculus sedangkan hari keempat dan kelima tidak di temukan tikus.

Hasil penangkapan tikus diperoleh sebanyak 17 ekor, dengan jenis Mus musculus, Rattus rattus diardii dan Rattus norvegicus (Tabel 2). Ditemukan 1 ekor tikus yang terinfestasi pinjal yaitu jenis Rattus rattus diardii dengan spesies pinjal Xenopshylla cheopis yang ditangkap pada bangunan rumah. Jenis tikus yang dominan di wilayah studi adalah Mus musculus, sebanyak 10 ekor.

Tabel 2. Tikus Yang Tertangkap di Wilayah Kerja KKP Kuala Tungkal Tahun 2019

\begin{tabular}{|c|c|c|c|c|}
\hline No & Lokasi Perangkap & Jenis Spesies Tikus & $\mathrm{n}$ & $\%$ \\
\hline & Gudang & Mus musculus & 2 & 11,8 \\
\hline & & Rattus rattus diardii & 1 & 5,8 \\
\hline & & Rattus norvegicus & 2 & 11,8 \\
\hline \multirow[t]{3}{*}{2} & Bangunan Rumah & Mus musculus & 5 & 29,4 \\
\hline & & Rattus rattus diardii & 2 & 11,8 \\
\hline & & Rattus norvegicus & & \\
\hline \multirow[t]{3}{*}{3} & Kebun sekitar rumah & Mus musculus & 0 & 0 \\
\hline & & Rattus rattus diardii & 0 & 0 \\
\hline & & Rattus norvegicus & 0 & 0 \\
\hline \multirow[t]{4}{*}{4} & Bangunan Perkantoran & Mus musculus & 3 & 17,6 \\
\hline & & Rattus rattus diardii & 0 & 0 \\
\hline & & Rattus norvegicus & 2 & 11,8 \\
\hline & Total & & 17 & 100 \\
\hline
\end{tabular}

Dari Tabel 2 terlihat bahwa jenis tikus Mus musculus dan Rattus norvegicus yang banyak di temui di gudang (11,8\%), sedangkan Rattus rattus diardii ditemukan hanya 1 ekor (5,8\%). Pada lokasi bangunan rumah, tikus yang paling dominan adalah Mus musculus 5 ekor (29,4\%), dan Rattus rattus diardii sebanyak 2 ekor $(11,8 \%)$. Di area kebun sekitar rumah tidak di temukan adanya tikus, sedangkan di bangunan perkantoran dominan adalah Mus musculus sebanyak 3 ekor (17,6\%), dan Rattus norvegicus sebanyak 2 ekor (11,8\%). 


\section{PEMBAHASAN}

1. Jenis Tikus yang tertangkap

Hasil penangkapan tikus yang dilakukan di KKP Jambi Wilayah Kerja Pelabuhan Kuala Tungkal dengan cara pemasangan perangkap tikus, didapatkan 17 ekor tikus dengan 3 jenis tikus yang berbeda yaitu Mus musculus, Rattus rattus diardi dan Rattus norvegicus (Tabel 2). Berdasarkan lokasinya, tikus diperoleh dari bangunan rumah, gudang, dan perkantoran. Sedangkan kondisi wilayah ditemukan tikus adalah terdapat tumpukan sampah, bangunan tidak rapat tikus, serta terdapat sumber makanan tikus.

Hasil penelitian menunjukkan bahwa tikus di lokasi studi tergolong kedalam jenis domestik yaitu bergantung dengan aktivitas manusia yang biasanya hidup di rumah, gudang dan kantor. Tikus sangat menyukai tempat gelap, kotor seperti atap rumah, sela-sela dinding, sisa-sisa bahan bangunan serta tempat sumber pakan. Populasi tikus dipengaruhi oleh faktor lingkungan, seperti air, sarang, sumber pakan, patogen, predator, tikus lain dan manusia (Joharina et al., 2016; Priyotomo et al., 2015).

Sanitasi lingkungan yang kurang baik di wilayah Pelabuhan Kuala Tungkal, mendukung perkembangbiakan tikus. Tumpukan sampah di bawah rumah, dan genangan air kotor menjadi tempat yang disenangi tikus, karena tersedianya sumber makanan. Sanitasi lingkungan yang kurang baik sangat berperan terhadap kepadatan tikus di suatu wilayah (Joharina et al., 2016). Pergerakan dan perkembangan tikus ditentukan oleh sumber makanan, air dan tempat persembunyian (Priyotomo et al., 2015).

- Angka keberhasilan penangkapan tikus dipengaruhi kualitas perangkap, umpan yang tepat dan kepadatan tikus yang realtif tinggi (Priyotomo et al., 2015). Pada penelitian ini, pada hari pertama diperoleh 10 ekor tikus pada pemasangan perangkap selama15 jam $(0,7$ jam/ekor), hari kedua diperoleh 5 ekor selama 15 jam (0,3 jam/ ekor0, hari ketiga diperoleh 2 ekor (0,1 jam/ekor). Sedangkan banyaknya jumlah tikus yang tertangkap selama 5 hari sebanyak 17 ekor, atau $3-4$ ekor tikus per hari.

Tikus yang didapatkan di Pelabuhan Kuala Tungkal dapat meningkatkan risiko terjadinya penularan penyakit, mengingat tikus sebagai inang ektoparasit yang dapat menggigit manusia dan mengakibatkan infeksi. Perbaikan sanitasi lingkungan sangat penting dilakukan untuk menekan populasi tikus sebagai inang ektoparasit dari Xenopshylla cheopis.

\section{Ektoparasit yang di temukan}

Hasil penelitian mendapatkan tikus yang mengandung ektoparasit Xenopshylla cheopis, adalah jenis tikus Rattus rattus diardii. Hasil ini mengindikasikan bahwa Xenopshylla cheopis lebih suka pada tikus rumah seperti Rattus rattus diardii. Kesukaan pinjal pada tikus rumah karena kondisi sarang tikus yang kering. Larva pinjal tidak dapat bertahan lama pada kondisi lingkungan yang lembab (Dewi \& Susanti, 2019; Mutaqin et al., 2016).

Menurut Van der Mescht dalam Ristiyanto (2016) bahwa kepadatan pinjal berdasarkan tipe pinjalnya, apakah host specific atau host opportunistic, serta mikro habitatnya (flur-flea atau nest-flea). Xenopshylla cheopis tergolong kedalam host opportunistic, kemungkinan temperature dan curah hujan di Kuala Tungkal sangat sesuai untuk perkembangan pinjal (Ristiyanto et al., 2016). Hasil ini sejalan dengan penelitiannya Ristiyanto (2016), pemasangan perangkap tikus yang dilakukan di daerah Balai Besar Penelitian dan Pengembangan Vektor dan Reservoir Penyakit (B2P2VR), Salatiga, mendapatkan keberadaan pinjal terbanyak pada tikus Rattus diardii. Xenopshylla cheopis tergolong dalam pinjal domestik yang dominan habitatnya di dalam rumah, hidupnya berada di badan dan di sarang tikus rumah. Perkembangan pinjal ini membutuhkan kondisi kering seperti yang terdapat pada sarang tikus rumah yang lebih senang hidup di tempat yang kering.

Menurut Hadi (2017), pinjal mengalami metamorfosa sempurna, pinjal akan meninggalkan inangnya untuk meletakkan telurnya pada tempat-tempat yang dekat dengan inangnya seperti sarang tikus, celahcelah lantai atau karpet, diantara debu dan kotoran organic, atau di bulu-bulu inangnya. Pinjal dewasa akan menghindari cahaya dan akan tinggal di antara rambut inangya, karena tidak semua pinjal mempunyai kekhususan inang (host specific). Ektoparasit Xenopshylla cheopis disebut sebagai kutu tikus tropis yang merupakan parasit dari tikus terutama tikus Rattus. Xenopshylla cheopis yng ditemukan pada 
tubuh Rattus diardii bisa terjadi karena habitat hidup pinjal yang suka di dalam rumah dan di tempat yang kering serta host opportunistic (Hadi \& Supriyono, 2017).

Ektoparasit yang didapatkan dipastikan sebagai pinjal berdasarkan kunci identifikasi dan berdasarkan Permenkes Nomor 50 Tahun 2017 dengan ciri-ciri, antara lain tidak bersayap, kaki kuat dan panjang, mempunyai mata tunggal, segmentasi tubuh tidak jelas (batas antara kepala dan dada). Walaupun ektoparasit hanya satu ekor namun perlu dilakukan pengawasan dan upaya pengendalian, tidak hanya di daerah pelabuhan yang cenderung memiliki mobilitas tikus yang tinggi, juga daerah pemukiman di sekitar pelabuhan. Penyebaran tikus dipengaruhi oleh berbagai faktor yang sangat bervariasi, rentang wilayah, kondisi lingkungan, serta keberadaan sumber makanan (Kementerian Kesehatan RI, 2017).

Walaupun pada tahun-tahun sebelumnya tidak ditemukan ekstoparasit, hal ini berpotensi besar terjadinya sebaran penyakit yang disebabkan oleh ekstoparasit tersebut. Penyakit pes atau sampar adalah penyakit yang disebabkan oleh infeksi bakteri yersinia pestis, dengan tandatanda sakit serta gangguan pada peredaran darah, pembesaran kelenjar getah bening, bahkan gangguan gejala paru-paru.

\section{SIMPULAN}

Tikus yang dominan terdapat di wilayah kerja Pelabuhan Kuala Tungkal adalah Musmusculus. Ditemukan tikus yang mengandung ektoparasit Xenopshylla cheopis, yaitu pada tikus jenis Rattus diardii. Perlu dilakukan pengawasan dan upaya pengendalian tindak hapus tikus dan perbaikan sarana sanitasi di lingkungan Kantor Kesehatan Pelabuhan Kuala Tungkal dengan cara meniadakan tempat persembunyian tikus, membersihkan lingkungan sekitar dan meniadakan tempat makanan.

\section{UCAPAN TERIMA KASIH}

Ucapan terima kasih kepada Kepala Kantor Kesehatan Pelabuhan Kuala Tungkal, Provinsi Jambi atas ijin dan kemudahan data yang diberikan.

\section{DAFTAR PUSTAKA}

Dewi, W. M., \& Susanti, R. (2019). Ectoparasite Prevalence in Rats as Zoonosis Risk Mapping at the Coastal Inundation Area in Semarang City. Jurnal Ekologi Kesehatan, 18(3), 171-182.

Hadi, U. K., \& Supriyono. (2017). Ektoparasit. PT Penerbit IPB Press.

Ibrahim, E., Manyullei, S., \& Sumarni. (2018). Jurnal Nasional Ilmu Kesehatan. Jurnal Nasional Ilmu Kesehatan, 1(2), 1-16. http://journal.unhas.ac.id/index.php/jnik/index Joharina, A., Mulyono, A., Sari, T., Rahardianingtyas, E., Bagus, D., \& Ristiyanto, R. (2016). Rickettsia pada Pinjal Tikus (Xenopsylla Cheopis) di Daerah Pelabuhan Semarang, Kupang dan Maumere. Buletin Penelitian Kesehatan, 44. https://doi.org/10.22435/bpk.v44i4.4920.237244

Kementerian Kesehatan RI. (2008). Peraturan Menteri Kesehatan RI Nomor 356/MENKES/PER/IV/2008 Tentang Organisasi dan Tata Kerja KKP. In Peraturan Menteri Kesehatan RI (p. 14). www.kkpyogyakarta.com Kementerian Kesehatan RI. (2013). Peraturan Menteri Kesehatan RI Nomor 34/2013 Tentang Penyelenggaraan Tindak Hapus Tikus dan Hapus Serangga Di Pelabuhan, Bandar Udara dan Pos Lintas Batas Darat Jakarta.

Kementerian Kesehatan RI. (2014). Peraturan Menteri Kesehatan RI Nomor 44/2014 Tentang Penyelenggaraan Pelabuhan dan Bandar Udara Sehat.

Kementerian Kesehatan RI. (2017). Peraturan Menteri Kesehatan RI Nomor 50/2017 Tentang Standar Mutu Kesehatan Lingkungan dan Persyaratan Kesehatan Vektor dan Binatang Pembawa Penyakit Serta Pengendaliannya.

KLW, S. P. dan. (2017). Laporan Evaluasi KKP. Kantor Kesehatan Pelabuhan Kelas III Jambi. Misbahul Subhi (2018) Pengamatan Tikus dan Pinjal Dalam Upaya Pengendalian Risiko Lingkungan di Wilayah Kerja Bandara Abdur Rahman Saleh Kantor Kesehatan Pelabuhan Kelas II Probolinggo. Seminar Nasional Penelitian dan Pengabdian Masyarakat2018LP4MP Universitas Islam Majapahit

Mutaqin, A. K. A., Ngadino, \& Thohari, I. (2016). Keberhasilan Penangkapan Tikus (Trap Success) dan Indeks Pinjal di Desa Kayukebek Kabupaten Pasuruan Tahun 2016. Jurnal Poltekkes Depkes Surabaya, 14(2), 94-99. https://doi.org/https://doi.org/10.3929/ethz-b000238666 
Pelabuhan, K. K. (2016). Port Health Authority. Kesehatan Pelabuhan Seluruh Indonesia.

Priyotomo, Y. C., Santoso, L., Martini, \& Hestiningsih, R. (2015). Studi Kepadatan Tikus dan Ektoparasit di Daerah Perimeter dan Buffer Pelabuhan Laut Cilacap. Jurnal Kesehatan Masyarakat (e-Journal), 3(April), 86-96.

Ristiyanto, R., H, F. D., Mulyono, A., \& Hadi, T. R. (2016). Ektoparasit Tungau Trombikulid Dan Inangnya Serta Peluang Penularan Scrub Typhus Di Beberapa Daerah Pulau Jawa. Vektora: Jurnal Vektor Dan Reservoir Penyakit, $8(1), 41-52$.

https://doi.org/10.22435/vk.v8i1.4426.41-50
Rusmini. (2011). Bahaya Leptospirosis. Gosyen Publishing, Yogyakarta.

SyamsuarManyullei1,Agus Bintara Birawida1, Izmi Fhadilla Sulema (2010) Studi 2019. Kepadatan Tikus dan Ektoparasit di Pelabuhan laut Soekarno Hatta Tahun 2019 Jurnal Nasional Ilmu Kesehatan (JNIK) Volume 2. Edisi 2

Yuliadi, B., Muhidin, \& Indriyani, S. (2016). Tikus Jawa, Teknik Survei Di Bidang Kesehatan. Badan Penelitian dan Pengembangan Kesehatan, Jakarta. 